\title{
Development of Lab-to-Fab Production Equipment Across Several Length Scales for Printed Energy Technologies, Including Solar Cells
}

\author{
Hösel, Markus; Dam, Henrik Friis; Krebs, Frederik C
}

Published in:

Energy Technology

Link to article, DOI:

10.1002/ente.201402140

Publication date:

2015

Document Version

Publisher's PDF, also known as Version of record

Link back to DTU Orbit

Citation (APA):

Hösel, M., Dam, H. F., \& Krebs, F. C. (2015). Development of Lab-to-Fab Production Equipment Across Several Length Scales for Printed Energy Technologies, Including Solar Cells. Energy Technology, 3(4), 293-304. https://doi.org/10.1002/ente.201402140

\section{General rights}

Copyright and moral rights for the publications made accessible in the public portal are retained by the authors and/or other copyright owners and it is a condition of accessing publications that users recognise and abide by the legal requirements associated with these rights.

- Users may download and print one copy of any publication from the public portal for the purpose of private study or research.

- You may not further distribute the material or use it for any profit-making activity or commercial gain

- You may freely distribute the URL identifying the publication in the public portal 


\title{
Development of Lab-to-Fab Production Equipment Across Several Length Scales for Printed Energy Technologies, Including Solar Cells
}

\author{
Markus Hösel, Henrik F. Dam, and Frederik C. Krebs*[a]
}

\begin{abstract}
We describe and review how the scaling of printed energy technologies not only requires scaling of the input materials but also the machinery used in the processes. The general consensus that ultrafast processing of technologies with large energy capacity can only be realized using roll-to-roll methods is taken as a premise, and thus the progression from a highly successful laboratory technique (i.e., spin coating) to large-scale roll-to-roll equipment is described in terms of all of the intermediate steps that must be available to make the transfer possible. Spin coating is compatible with materials
\end{abstract}

availability on the small scale and efficient scaling of equipment is a demanding task that must be performed in parallel with increasing materials availability. We outline that 3-5 processing platforms are necessary to efficiently take the laboratory technology to a version that represents the lower end of the industrial scale. The machinery bridges the gap through firstly achieving improved ink efficiency without surface contact, followed by better ink efficiency at higher speeds, and finally large-area processing at high speed with very high ink efficiency.

\section{Introduction}

The strong drive towards upscaling of printed energy technology such as fuel cells, supercapacitors, batteries, and photovoltaics (PV), and in particular organic photovoltaics (OPV), has led to an increasing interest for finding production methods that are ultimately compatible with large-scale processing. So far the primary manufacturing method for organic solar cells has been spin coating of polymers or evaporation of small-molecule active layers on glass substrates with a sputtered indium-tin oxide (ITO) layer as transparent conductive electrode. Back electrodes have generally been produced by vacuum deposition of aluminum or silver, whereas charge-selective layers are generally spin coated or vacuum deposited. Other solution-processible PV technologies such as dye-sensitized solar cells (DSSC), copper indium gallium selenide (CIGS), or perovskite cells can also potentially utilize large-scale printing and coating steps for several layers but are mostly processed using spin coating and further non-solution-based processes including high-temperature steps.

The main focus in this report is on how to bridge the gap between the small laboratory scale and the envisaged industrial scale. The scaling of a technology requires a scaling of equipment, and this equipment scaling effort is described mostly in the context of OPVs with solution-based active and functional layers (though other printed PV technologies will be highlighted as well). Spin coating and doctor blading have so far shown the highest efficiencies for OPV, leading to reported efficiencies beyond $10 \% .^{[1,2]}$ However, the high efficiencies have primarily been shown on small-sized cells in the sub-cm ${ }^{2}$ region, ${ }^{[3]}$ which are far from what solar cell product is expected to ultimately become. Large-area modules have been manufactured to produce a much higher power output than small test cells, but the performance is still far from the record devices. ${ }^{[4-6]}$ The main challenges are the change in the fabrication environment and machinery and of course also the availability of high-performance materials in larger quantities that are required as the scale increases (at a reasonable cost that enables the development).

A few laboratories and companies have been involved in research on upscaling the fabrication of OPV and printed PV to production levels with industrial potential. Roll-to-roll (R2R)-based processing can be seen as the most favorable method to generate a large output of OPV devices. Hundreds of labs and thousands of researchers all around the world are optimizing small-scale devices and find new materials but large-scale processing of OPV devices is limited to a small group of just a few research facilities and companies. These groups are often located within "printed electronics" hubs and can be found, for example, in the Netherlands, Finland, Germany, Korea, Australia, USA, UK, Brazil, China, and Denmark. Just a few of these groups (such as those in Denmark) have actually shown massive-scale R2R-produced OPV devices for which all layers are printed and coated. In many other cases the devices were finalized in separate pro-

[a] Dr. M. Hösel, Dr. H. F. Dam, Prof. F. C. Krebs Department of Energy Conversion and Storage Technical University of Denmark

Frederiksborgvej 399, DK-4000 Roskilde (Denmark) E-mail:frkr@dtu.dk

(1) This manuscript is part of a Special Issue on printed energy technologies. A link to the issue's Table of Contents will appear here. This text will be updated once the Special Issue is assembled. 
cesses (such as electrode evaporation) to demonstrate the large-scale processing of some of the layers (or just a single one).

The availability of OPVs and DSSCs for mass markets has not yet fully developed in spite of approximately 25 years of existence, researchers have attempted to find niche markets to compete with conventional silicon based devices that show higher efficiencies and longer operational lifetime. The fast low-temperature fabrication and low cost might be help to bring success, but being inherently meaningful only in a highvolume context makes the compatibility with niche markets a contradiction. The bankruptcy of Konarka in 2012, the only industrial OPV producer at this time, has not necessarily helped to foster commercialization of OPV. The former Nanosolar Inc., a manufacturer of R2R solution-processed CIGS modules, also struggled in the commercialization of their technology and went bankrupt. Several smaller companies have also seen their defeat on a commercial market (i.e., Plextronics). Nevertheless, OPV technology and R2Rprocessed PV still form a highly interesting field of research with a great future due to researchers' vision of a cheap fabrication principle [represented in companies such as Armor, Eight19, infinityPV, Belectric OPV, Solarmer (hybrid), Heliatek (only evaporation), GCell (DSSC)]; in addition, a new rising star in the form of perovskite-based PV has been subject to an immense interest in the recent months and already has commercialization on the horizon (Oxford PV, Dyesol). ${ }^{[7,8]}$ The efficiencies for perovskite-based PV (in the prototypical form of a conventional DSSC with a lead-halide absorber) are reportedly already at the level of Si solar cells but the lifetime, toxicity, and especially upscaling and robustness in application have yet to be solved and demonstrated beyond existing academic reports. Methods for decreasing the risk for large-scale OPV manufacturing and other emerging PV technologies include reducing the gap between largeand small-scale cells and increasing the compatibility between the manufacturing methods used in small- and largescale processing. Furthermore, a practical route from labora-

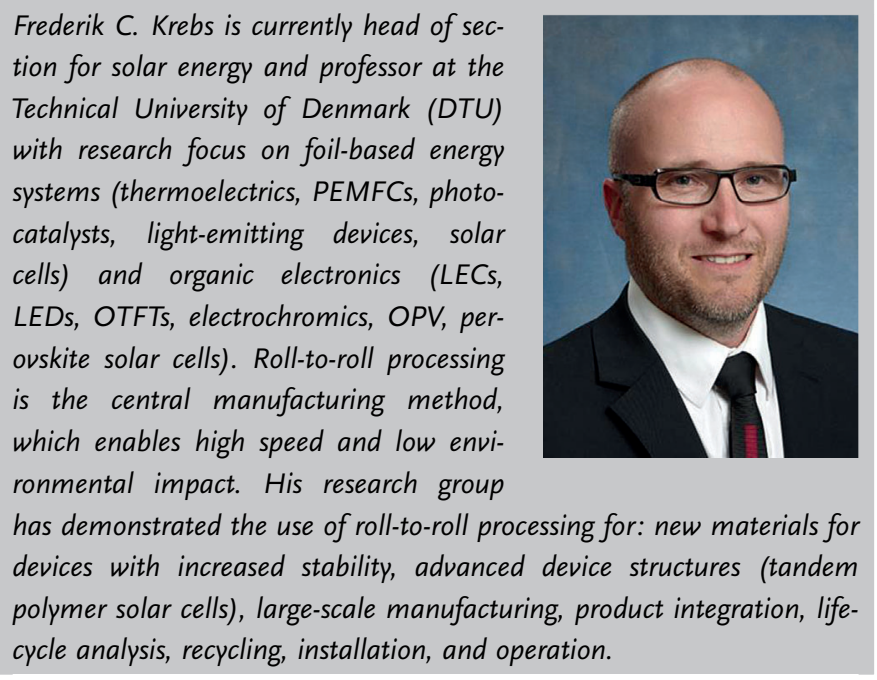

tory-scale to fabrication level (lab to fab) equipment has to be established, which we will focus on here.

\section{Solution-Processed PV: From Lab to Fab}

Polymer solar cells, the most promising candidate in printed $\mathrm{PV}$, are generally manufactured in either normal or inverted structures, where normal and inverted refer to the direction in which the charge carriers are extracted. In a normal-structure OPV cell the electrons will go through an electron conductor to the back electrode and the holes will go through a hole conductor to the front electrode, whereas in the inverted device, the order of electron/hole conductors are reversed. The light-absorbing photoactive layer is sandwiched between the electrodes and generates the charge carriers upon illumination. The main advantage of an inverted device structure is a better compatibility with full solution processing of all layers including electrodes (mainly silver or carbon) whereas the normal device structure cells often require evaporation of buffer layers and reactive electrodes. For further insights into the functionality, physics, and chemistry of OPVs we refer to reviews published elsewhere. ${ }^{[9-15]}$

In inorganic CIGS thin-film solar cells the copper indium gallium selenide absorber in a chalcopyrite crystal structure is typically sandwiched between a molybdenum back contact and a transparent $\mathrm{CdS}, \mathrm{ZnO}, \mathrm{Al}$-doped $\mathrm{ZnO}$ front contact. It has been shown that the absorber layer can be solution processed from CIGS precursors or CIGS nanoparticle inks but they require selenization steps and high-temperature postprocessing. ${ }^{[16-18]}$ Efficiencies beyond $15 \%$ have been achieved. ${ }^{[19]}$

Another candidate for printed PVs is dye-sensitized solar cells (DSSC), whereby the photoelectrochemical system typically relies on a mesoporous oxide layer $\left(\mathrm{TiO}_{2}\right)$ coated with photosensitizer dye (e.g., a ruthenium complex) sandwiched together with an electrolyte between the electrodes. ${ }^{[20]}$ All "solid-state" devices are actively researched to overcome the sealing challenges of the liquid electrolyte. ${ }^{[21]}$ The printed components in such devices are often mesoporous layers and electrodes rather than the full device. The dyes and electrolytes are typically immersed using drop casting or dipping processes. DSSCs show a strong industrial engagement with multiple application demonstrators and projects for building integrated photovoltaics as summarized in a comprehensive roadmap. ${ }^{[22]}$ Efficiencies up to $13 \%$ could be achieved through molecular engineering of porphyrin sensitizers. ${ }^{[23]}$

The latest developments for solution-processible solar cells are metal organohalide perovskite solar cells that have similar structures to DSSCs but do not rely on an electrolyte. Several layouts from planar to mesoscopic embodiments emerged and efficiencies in the range of 15-20\% have been achieved. ${ }^{[7,8,24]}$ Methylammonium lead iodide $\left(\mathrm{CH}_{3} \mathrm{NH}_{3} \mathrm{PbI}_{3}\right)$ is actively investigated as an active layer although lead has high toxicity. Replacing lead with tin is a promising way to improve on environmental issues but this compromises the performance. ${ }^{[25,26]}$ 
The printing and coating methods for fabrication of PV devices, their industrial upscaling potential, and the detailed cost and life-cycle analysis have mainly focused on OPV and this is covered in many reports. ${ }^{[27-35]}$ The main large-scale compatible process technologies are slot-die coating, screen printing, flexo printing, gravure, spraying, and inkjet. Even laser processing for scribing and welding has been studied. ${ }^{[36-38]}$ An overview of exemplary studies divided into desktop processing and proofing, small-scale single roll-based systems, small R2R setups, and a large-scale R2R setup with industrial character are summarized in Table 1 and Table 2. Table 3 covers some examples of solution-processible PVs other than OPV; most of the layers are still spin coated but potentially scalable to large-scale methods. The summaries also show whether or not evaporation or sputter steps were necessary for the device fabrication. Finding the right combination of stack design, fabrication method, process parameters, ink characteristics, layer thicknesses, surface interactions, and drying conditions should lead to the best results that can be fulfilled, also in an industrial environment. The final device should be manufactured with the most suitable methods for each of the functional layers in their optimal processing window rather than focusing on a single fabrication method throughout the production workflow of the multilayer device. Several reports have attempted to establish just one method, such as gravure printing, for the complete device fabrication but finally had to implement lab-scale processing steps such as evaporation on selected devices to show functionality. ${ }^{[39]}$ The economic and efficient route from small-scale devices to real applications by avoiding wasteful processes such as spin coating, etching, and shadow masking is described here mostly through examples of OPV, but this can be extended to all other printed PV technologies.

\section{Production equipment}

Desktop-based systems as illustrated in Figure 1 and shown in Figure $2 \mathrm{a}$ and $\mathrm{b}$ are widely used in laboratory environments to test new fabrication methods other than spin coating. They are available for all kinds of printing and coating methods and provide repeatable testing conditions. The footprint is very small and the equipment can often fit into

Table 1. Overview of OPV devices fabricated with different R2R-compatible methods using flatbed desktop proofing equipment.

\begin{tabular}{|c|c|c|c|c|c|c|c|c|}
\hline Structure & Conductive Substrate & Layer processed & Method & Evap. & $A_{\text {active }}\left[\mathrm{cm}^{2}\right]$ & PCE [\%] & Notes & Ref \\
\hline normal C & ITO & $\mathrm{HTL}, \mathrm{AL}$ & DB & $2 \times$ & 0.078 & 1.18 & & Ref. [40] \\
\hline normal C & ITO & $A L$ & DB & $1 \times$ & 0.04 & 6.49 & $9-24 \mathrm{~m} \mathrm{~min}^{-1}$ & Ref. [41] \\
\hline inverted C & ITO & $A L$ & DB & $2 \times$ & 0.05 & 4.4 & & Ref. [42] \\
\hline normal C & ITO & $A L$ & DB & $1 \times$ & 0.04 & 6.74 & $24 \mathrm{~m} \mathrm{~min}^{-1}, 35 \mathrm{~cm}^{2}$ coated & Ref. [41] \\
\hline normal C & Ag grid/PEDOT:PSS & FEL, AL & DB & $1 \times$ & n.a. & 3.36 & unknown $\mathrm{Ag}$ grid $\mathrm{R} 2 \mathrm{R}$ process & Ref. [43] \\
\hline normal C & ITO & $\mathrm{HTL}, \mathrm{AL}$ & $\mathrm{DB}, \mathrm{G}$ & $2 \times$ & n.a. & $1.6-3.6$ & processing study & Ref. [44] \\
\hline inverted C & ITO & $\mathrm{ETL}, \mathrm{AL}, \mathrm{HTL}$ & $G$ & $1 \times$ & 0.045 & 0.6 & $40 \mathrm{~m} \mathrm{~min}^{-1}$ & Ref. $[45,46]$ \\
\hline normal C & ITO & $\mathrm{HTL}, \mathrm{AL}$ & G & $1 \times$ & 0.03 & 1.68 & $60 \mathrm{~m} \mathrm{~min}^{-1}$ & Ref. [47] \\
\hline normal M & ITO & $\mathrm{HTL}, \mathrm{AL}$ & $\mathrm{G}$ & $2 \times$ & 15.45 & 1.92 & & Ref. [48] \\
\hline normal C & ITO & $\mathrm{HTL}, \mathrm{AL}$ & $G$ & $2 \times$ & 0.19 & 2.8 & $7-18 \mathrm{~m} \mathrm{~min}^{-1}$ & Ref. [49] \\
\hline inverted C & $\mathrm{Cr}, \mathrm{Al}, \mathrm{Cr}$ & $\mathrm{AL}, \mathrm{HTL}$ & SD & $4 \times$ & 2.25 & 2.8 & metal wrap through & Ref. [50] \\
\hline inverted $\mathrm{M}$ & $\mathrm{Cr}, \mathrm{Al}, \mathrm{Cr}$ & AL, HTL & SD & $4 \times$ & 13.2 & 2.5 & $1 \mathrm{~m} \mathrm{~min}^{-1}$, manual wiping & Ref. [51] \\
\hline normal C & ITO & $\mathrm{HTL}, \mathrm{AL}$ & SD & $1 \times$ & 1 & 3.07 & $0.3-5 \mathrm{~m} \mathrm{~min}^{-1}$ & Ref. [52] \\
\hline normal M & ITO & $\mathrm{HTL}, \mathrm{AL}$ & SD & $1 \times$ & 198 & 1.73 & $0.5-1 \mathrm{~m} \mathrm{~min}^{-1}$ & Ref. [6] \\
\hline inverted C & ITO & $\mathrm{ETL}, \mathrm{AL}, \mathrm{HTL}$ & SD & $1 \times$ & 1.6 & 1 & 2-10 $\mathrm{m} \mathrm{min}^{-1}$, coating window & Ref. [53] \\
\hline inverted C & ITO & $\mathrm{ETL}, \mathrm{AL}, \mathrm{HTL}$ & $\mathrm{DB}, \mathrm{SD}$ & $1 \times$ & 2.5 & 3.13 & $3 \mathrm{~m} \mathrm{~min}^{-1}$ & Ref. [54] \\
\hline Inverted M & ITO & $\mathrm{ETL}, \mathrm{AL}, \mathrm{HTL}$ & $\mathrm{DB}, \mathrm{SD}$ & $1 \times$ & 35 & 3.3 & laser patterning & Ref. [55] \\
\hline inverted $\mathrm{M}$ & ITO & $\mathrm{ETL}, \mathrm{AL}, \mathrm{HTL}$ & IJ & - & 11.1 & 2.09 & different IJ heads & Ref. [56] \\
\hline normal C & ITO & $A L$ & I) & $1 \times$ & 0.03 & 1.4 & & Ref. [57] \\
\hline normal C & Ag grid/PEDOT:PSS & FEL & IJ & $2 \times$ & 4 & 1.54 & & Ref. [58] \\
\hline normal C & ITO & $A L$ & IJ & $2 \times$ & 0.595 & 3.5 & test of chlorine free solvents & Ref. [59] \\
\hline normal C & ITO & $A L$ & IJ & $2 \times$ & 0.56 & 2.6 & test of annealing & Ref. [60] \\
\hline normal C & Ag grid/PEDOT:PSS & FEL, AL & I), Spray & $2 x$ & 4 & 2.47 & & Ref. [61] \\
\hline normal C & ITO & $\mathrm{HTL}, \mathrm{AL}$ & DB, IJ & $2 \times$ & 0.09 & 3.86 & & Ref. [62] \\
\hline inverted $\mathrm{M}$ & ITO & ETL, AL, HTL, BEL & SP & & 75 & 0.013 & all screen printed & Ref. [63] \\
\hline normal C & ITO & $A L$ & SP & $1 \times$ & 0.09 & 4.23 & modules tested & Ref. [64] \\
\hline inverted $\mathrm{M}$ & FTO & $\mathrm{ETL}, \mathrm{AL}, \mathrm{BEL}$ & Spray & - & 6 & 0.9 & up to 40 spray cycles & Ref. [65] \\
\hline inverted C & ITO & $\mathrm{ETL}, \mathrm{AL}, \mathrm{HTL}$ & Spray & $1 \times$ & 0.36 & 3.17 & shadow masking & Ref. [66] \\
\hline inverted C & ITO & $\mathrm{ETL}, \mathrm{AL}, \mathrm{BEL}$ & Spray & - & 0.36 & 2.41 & shadow masking & Ref. [67] \\
\hline normal C & ITO & $\mathrm{HTL}, \mathrm{AL}$ & Spray & $2 \times$ & 0.046 & 2.17 & & Ref. [68] \\
\hline normal C & ITO & $\mathrm{HTL}, \mathrm{AL}$ & Spray & $2 \times$ & 0.2 & 2.7 & & Ref. [69] \\
\hline inverted C & ITO & $\mathrm{AL}, \mathrm{HTL}, \mathrm{BEL}$ & SD, SP & - & 1 & $>1$ & SP flatbed & Ref. [70] \\
\hline inverted $\mathrm{M}$ & Ag grid/PEDOT:PSS & $\mathrm{AL}, \mathrm{HTL}, \mathrm{BEL}$ & $S D, F$ & - & 8 & 3.2 & & Ref. [71] \\
\hline inverted C & Ag grid/PEDOT:PSS & $\mathrm{AL}, \mathrm{HTL}, \mathrm{BEL}$ & $S D, F$ & - & 1 & 3.8 & & Ref. [72] \\
\hline inverted C & Ag grid/PEDOT:PSS & $E T L, A L, I L, H T L, B E L$ & $S D, F$ & - & 1 & 1.3 & 12 layers, tandem device & Ref. [73] \\
\hline inverted C & $\mathrm{Ag}$ & FEL, ETL, AL, HTL, BEL & $S D, F$ & & 0.8 & 2.39 & tandem device & Ref. [74] \\
\hline
\end{tabular}

$\mathrm{C}=$ cell, $\mathrm{M}=$ module, $\mathrm{HTL}=$ hole transport layer, $\mathrm{ETL}=$ electron transport layer, $\mathrm{AL}=$ active layer, $\mathrm{FEI}=$ front electrode, $\mathrm{BEL}=$ back electrode, $\mathrm{IL}=\mathrm{intermediate}$ layer, $\mathrm{DB}=$ doctor blading, $\mathrm{G}=$ gravure printing, $\mathrm{SD}=$ slot-die coating, IJ=inkjet printing, $\mathrm{SP}=\mathrm{screen}$ printing, $\mathrm{F}=$ flexo printing 


\begin{tabular}{|c|c|c|c|c|c|c|c|c|}
\hline Structure & Conductive Substrate & Layer processed & Method & Evap. & $\mathrm{A}_{\text {active }}\left[\mathrm{cm}^{2}\right]$ & PCE [\%] & Notes & Ref \\
\hline \multicolumn{9}{|c|}{ Small-scale R2R systems with small footprint or narrow web width (experimental machines) } \\
\hline normal C & ITO & $\mathrm{HTL}, \mathrm{AL}$ & G & $1 \times$ & 0.68 & 0.3 & $3.7-8.7 \mathrm{~m} \mathrm{~min}^{-1}$ & Ref. [75] \\
\hline normal C & ITO & $\mathrm{HTL}, \mathrm{AL}$ & $\mathrm{G}$ & $1 \times$ & 0.5 & 1 & $3.7 \mathrm{~m} \mathrm{~min}^{-1}$ & Ref. [76] \\
\hline inverted C & ITO & $\mathrm{AL}, \mathrm{ETL}$ & SD & $2 x$ & 1 & 2.4 & $1 \mathrm{~m} \mathrm{~min}^{-1}$, external drying & Ref. [77] \\
\hline normal C & ITO & $\mathrm{HTL}, \mathrm{AL}$ & SD & $1 \times$ & 0.25 & 1.74 & $1-4 \mathrm{~m} \mathrm{~min}^{-1}, 13 \mathrm{~m}$ air dryer & Ref. [78] \\
\hline inverted $\mathrm{M}$ & ITO & $E T L, A L, H T L, B E L$ & $S D, S P$ & - & 120 & 1.7 & $<2 \mathrm{~m} \mathrm{~min}^{-1}$, flatbed SP & Ref. [80] \\
\hline inverted $\mathrm{M}$ & $\mathrm{Ag}$ & $\mathrm{BEL}, \mathrm{ETL}, \mathrm{AL}, \mathrm{HTL}, \mathrm{FEL}$ & $S D, S P$ & - & 120 & 0.3 & $0.2-0.9 \mathrm{~m} \mathrm{~min}^{-1}$, flatbed SP & Ref. [81] \\
\hline inverted $\mathrm{M}$ & ITO & $\mathrm{ETL}, \mathrm{AL}, \mathrm{HTL}, \mathrm{BEL}$ & $S D, S P$ & - & 360 & 1.69 & $\leqq 2 \mathrm{~m} \mathrm{~min}^{-1}$, flatbed SP & Ref. [30] \\
\hline inverted C & $\mathrm{Zn}$ & Glue, AL, HTL & $G, F$ & - & 0.09 & 1.3 & $18-30 \mathrm{~m} \mathrm{~min}^{-1}$, paper substrate & Ref. [82] \\
\hline normal M & ITO & HTL, AL & G & $2 \times$ & 6 & 1.6 & & Ref. [83] \\
\hline \multicolumn{9}{|c|}{ Large-scale R2R systems with large footprint, large web width and high speed capabilities (close to industrial machinery) } \\
\hline inverted C & $\mathrm{Cr}, \mathrm{Al}, \mathrm{Cr}$ & $\mathrm{AL}, \mathrm{HTL}$ & SD & $4 \times$ & 1.1 & 2.9 & $1 \mathrm{~m} \mathrm{~min}^{-1}$, aerosol jet tested & Ref. [84] \\
\hline normal $M$ & ITO & HTL, AL & SD & $2 \times$ & 21 & 0.7 & $10 \mathrm{~m} \mathrm{~min}^{-1}$, manuel patterning & Ref. [85] \\
\hline inverted $\mathrm{M}$ & ITO & ETL, AL, HTL, BEL & SD, SP & - & 35.5 & 2.75 & $<2 \mathrm{mmin}^{-1}$, full $\mathrm{R} 2 \mathrm{R}$ & Ref. [86] \\
\hline inverted $\mathrm{M}$ & Ag grid/PEDOT:PSS & FEL, ETL, AL, HTL, BEL & $F, S P, S D$ & - & 66 & 1.6 & 2-10 $\mathrm{m} \mathrm{min}^{-1}$, full $R 2 R$, inline & Ref. [87] \\
\hline inverted $\mathrm{M}$ & Ag grid/PEDOT:PSS & FEL, ETL, AL, IL, HTL, BEL & $F, S P, S D$ & - & 52.2 & 1.76 & $<20 \mathrm{~m} \mathrm{~min}^{-1}$, full R2R, tandem & Ref. [88] \\
\hline inverted $\mathrm{M}$ & Ag grid/PEDOT:PSS & FEL, ETL, AL, HTL, BEL & $F, S P, S D$ & - & 147000 & 2 & $<20 \mathrm{~m} \mathrm{~min}^{-1}$, full R2R, 21000 cells & Ref. [5] \\
\hline inverted $\mathrm{M}$ & Ag grid/PEDOT:PSS & FEL, ETL, AL, HTL, BEL & $F, S P, S D$ & - & 57 & 1.82 & $<20 \mathrm{~m} \mathrm{~min}^{-1}$, full R2R & Ref. [89] \\
\hline inverted $\mathrm{M}$ & PEDOT:PSS & FEL, ETL, AL, HTL, BEL & SP, SD & - & 30 & 1.85 & 4-10 $\mathrm{m} \mathrm{min}^{-1}$, full R2R, silver free & Ref. [90] \\
\hline inverted C & Ag grid/PEDOT:PSS & FEL, ETL, AL, HTL, BEL & $F, I J, I P, S D, S P$ & - & 6 & $<1.9$ & $0.5-25 \mathrm{~m} \mathrm{~min}^{-1}$, full $\mathrm{R} 2 \mathrm{R}$ & Ref. [91] \\
\hline normal M & ITO & $\mathrm{HTL}, \mathrm{AL}$ & G & $2 \times$ & 15 & 1.86 & $8 \mathrm{mmin}^{-1}$ & Ref. [39] \\
\hline
\end{tabular}

\begin{tabular}{|c|c|c|c|c|c|c|c|c|}
\hline Type & $\begin{array}{l}\text { Conductive Sub- } \\
\text { strate }\end{array}$ & Layer processed & Method & $\begin{array}{l}\text { Evap. Sput- } \\
\text { ter }\end{array}$ & $\begin{array}{l}A_{\text {active }} \\
{\left[\mathrm{cm}^{2}\right]}\end{array}$ & $\begin{array}{l}\text { PCE } \\
{[\%]}\end{array}$ & Notes & Ref \\
\hline CIGS & Mo & $\mathrm{CIG}, \mathrm{CdS}$ & SC & yes & 0.09 & 8.01 & $\begin{array}{l}\text { spray + inkjet suggested, selenization, sput- } \\
\text { tering }\end{array}$ & Ref. [92] \\
\hline CIGS & Mo & $\begin{array}{l}\mathrm{CICS}, \mathrm{CdS}, \mathrm{ZnO} \\
\mathrm{AgNW}\end{array}$ & SC & & 0.1 & 1.6 & claimed printing process, but just SC used & Ref. [93] \\
\hline CIGS & Mo & CIGS & SC & yes & n.a. & 15.2 & hydrazine & Ref. [19] \\
\hline CIGS & Mo & $\mathrm{CIG}$ & リ & yes & 0.04 & 5.04 & selenization & Ref. [96] \\
\hline CIGS & Mo & $\mathrm{CIG}$ & DB & yes & 0.5 & 11 & selenization & Ref. [97] \\
\hline DSSC & FTO & $\mathrm{TiO}_{2}$ & SP & yes & 0.96 & 3.66 & $\begin{array}{l}\text { various steps for dye and electrolyte, trans- } \\
\text { parent }\end{array}$ & Ref. [98] \\
\hline DSSC & FTO & $\mathrm{TiO}_{2}, \mathrm{Ti}, \mathrm{AgNW}$ & $\begin{array}{l}\text { spray, } \\
\text { DB }\end{array}$ & & 0.2 & 3.6 & dye immersion & Ref. [99] \\
\hline DSSC & ITO & $\mathrm{TiO}_{2}, \mathrm{SnO}_{2}$ & $\mathrm{DB}, \mathrm{G}$ & & 1 & 5.1 & & Ref. [100] \\
\hline perovskite & ITO & perovskite precursor & spray & yes & 0.025 & 11.1 & & Ref. [102] \\
\hline perovskite & FTO & $\mathrm{TiO}_{2}, \mathrm{ZrO}_{2}$, carbon & $\begin{array}{l}\text { spray, } \\
\text { SP }\end{array}$ & & 0.07 & 12.8 & drop casted perovskite & Ref. [103] \\
\hline perovskite & FTO & $\mathrm{TiO}_{2}$ & $\begin{array}{l}\text { spray, } \\
\text { SP }\end{array}$ & yes & 16.8 & 5.1 & SC of perovskite and other layers, module & Ref. [104] \\
\hline perovskite & FTO & $\mathrm{TiO}_{2}$ & spray & yes & 0.285 & 15 & SC of perovskite and other layers & Ref. [105] \\
\hline perovskite & FTO & carbon & DB & & 0.12 & 8.31 & $\begin{array}{l}\text { SC of perovskite and other layers, all ambi- } \\
\text { ent }\end{array}$ & Ref. [106] \\
\hline
\end{tabular}

a fume hood or even glove box for inert atmospheric conditions. Low ink consumption, low ink waste for large areas, and easy handling are an advantage for beginning studies of new fabrication processes. The maximum substrate size and deposition area is typically in the range of an A4 sheet $(21 \times$ $30 \mathrm{~cm}^{2}$ ) or smaller depending on the processing method. Sub- strates can be rigid (e.g., glass or flexible foils) depending on the construction of the printing station. After deposition of the functional inks the substrates are often transferred into separate dryers or onto hotplates before further processing. The parameters found in these experiments are often beyond the limits of upscaled machinery and the conditions cannot 


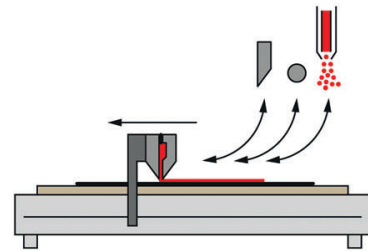

a) Coating

(Slot-die, blade, rod, spray)

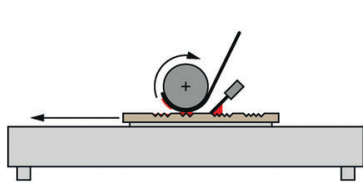

b) Printing (Gravure / flexo / offset)

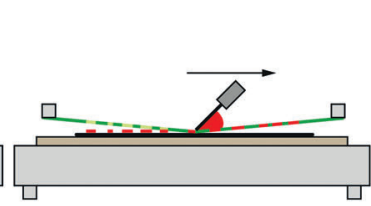

c) Printing (Screen printing)

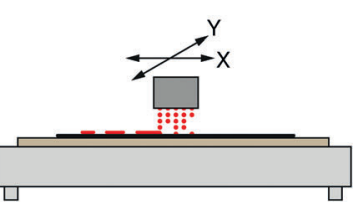

d) Printing

Figure 1. Desktop flatbed printing and coating proofing systems.
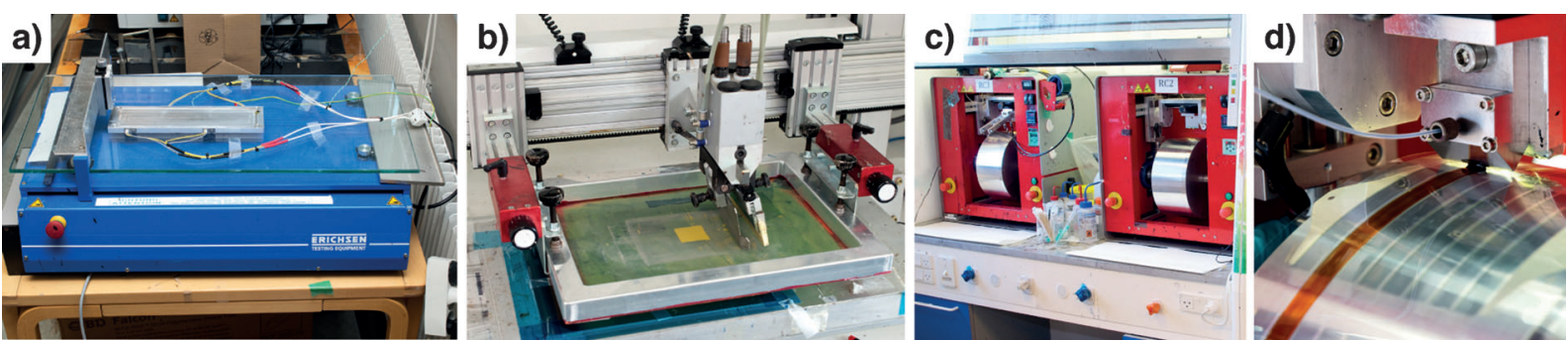

Figure 2. a) Flatbed coating system for knife, bar, or slot-die coating. b) Flatbed screen printing machine. c, d) Small-scale mini roll coater for slot-die coating and flexo printing. All shown machines can fit into fume hoods or glove boxes.

be directly transferred to R2R-based manufacturing systems due to the lack of suitably integrated drying systems. Good examples are OPVs fabricated with gravure printing proofers at $40-60 \mathrm{~m} \mathrm{~min}^{-1}$ with drying times from several minutes to hours as listed in Table 1 . These small test machines allow the scenarios of printing at very high speed and separate drying because the wet layer does not come into contact with additional rollers, as would happen on a conventional R2R machine for which the deposited layer has to be dried before first contact with a roller. The desktop-based systems allow only batch-wise sheet-to-sheet processing, with unrealistically slow post-printing conditions.

Roll-based systems overcome some of the limitations in substrate size and enable continuous deposition over larger areas and longer times. Small-scale systems as illustrated in Figure 3 are typically made for web widths of up to $150 \mathrm{~mm}$.
The typical substrates are flexible foils rather than glass although ultra-thin flexible glass is under development and in and in an early commercialization phase.$^{[107-109]}$ Process dependent run-in length (e.g., due to meniscus stabilization in slot-die coating) can be handled more easily because the overall coating length only relies on the roll length or circumference of the drum.

The mini rollcoater (MRC, as illustrated in Figure $3 \mathrm{a}$ and shown in Figure $2 \mathrm{c}$ and d) was developed at the Technical University of Denmark (DTU) and is now commercially available as a lab-scale coater ${ }^{[70,110]}$ suited for testing polymers and OPV stacks with slot-die processing methods; in contrast to spin-coating methods, this promises a quicker scaling of optimizations and verification of large-scale compatibility for new materials and inks. The system consists of a drum (diameter $=300 \mathrm{~mm}$ ) driven by a servomotor at a speed range of up to $2 \mathrm{mmin}^{-1}$. The drum can be heated up to $140^{\circ} \mathrm{C}$ for contact heating of the coated surface, replicating the parameter space previously used for slotdie coating. ${ }^{[30,80,111]}$ The MRC can be equipped with a mini slot-die head with minimized dead volume and enables several continuous coating stripes side-by-side on a substrate length of approximately $1 \mathrm{~m}$. The shift of the slot-die head enables the variation of parameters between each stripe (e.g., thickness, speed, ink composition) and allows precise over 
coating with offsets as required for the device fabrication. The typical consumption for a single $1 \mathrm{~m}$-long and $10 \mathrm{~mm}$ wide stripe of active layer coated with a dry layer thickness of $200 \mathrm{~nm}$ is less than $0.2 \mathrm{~mL}$ of ink. The coated layers will be dried while on the machine and will never touch any surface. Device finalization is realized through a flexo printing head that allows patterned printing of contact pads and electrode layers made from silver ink. The MRC can be used with any type of flexible substrate covered with pre-structured ITO or preferably with ITO-free conductive electrodes such as the Flextrode stack. It was successfully used to test new polymers ${ }^{[72,112]}$ or even tandem stacks ${ }^{[73]}$ that were later transferred to a full-sized R2R environment. ${ }^{[8]}$ Conductive electrodes such as silver can also be directly coated on the machine with bare substrates as raw materials. ${ }^{[7]}$ The MRC has also proven to be useful in the development of electrochromic polymers and devices, and spray coating has been implemented for continuous large-area film deposition. ${ }^{[113]}$

Sheet-based and single-roll systems are useful for testing the ink compatibilities on a slightly increased scale compared to spin coating. The next step for upscaling is to increase the coating speed and substrate length. This will often be limited by the amount of substrate available, the drying power, and the time until a stabilized ink deposition takes place. A small-scale mini R2R coater was therefore developed together with Grafisk Maskinfabrik (GM) to allow a hybrid testing method, where ink and substrate consumption could be kept low, so that the possibility of testing the performance of inks and materials at higher coating speeds could be performed. Figure $3 \mathrm{~b}$ shows a schematic with a very simplified substrate path through such a machine. A photograph of a development machine is shown in Figure $4 \mathrm{a}$. This particular type of machine from GM allows testing at up to $30 \mathrm{~m} \mathrm{~min}^{-1}$, however the limited drying power/space available does not allow for use of inks for which a large amount of solvent has to be extracted. For this, a larger drying section has to be included, or supporting equipment (such as infrared heaters) is necessary. Current deposition equipment consists of slot-die coating and flexo printing, but additional methods such as inkjet printing are possible to integrate with further customization. Installation of corona treatment and edge guides allows further simulation of a final large-scale R2R environment. The typical web width is in the range of $100 \mathrm{~mm}$ and similar systems are available on the market, which were used for the fabrication of the OPV devices with different fabrication methods as summarized in Table 2. The footprint of such mini R2R systems is relatively small so that they can be moved around and even fit into a large walk-in fume hood. Integrated housing for controlled atmosphere is also possible.

Large-scale R2R machinery, as schematically illustrated in Figure 5, is used for testing industrially relevant processes or actual commercial production depending on size and output capacity. Such machines (Figure $4 \mathrm{~b}$ and c) have typical web widths of at least $300 \mathrm{~mm}$ and configurations with interchangeable printing and coating units, or multiple deposition stations in an inline configuration. The speed range has to be very wide to allow long drying times at low speeds, but also speeds of at least $20 \mathrm{~m} \mathrm{~min}^{-1}$ are desired to enable good conditions for printing methods such as flexo and gravure printing. Drying systems (e.g., hot air, infrared, etc.) after each printing and coating station should be of high capacity and must enable the evaporation of solvents at any given speed before the first contact of the printed surface with rollers. The process parameters (inks, speeds, drying, and annealing conditions) should be optimized against each other such that external long-term drying steps are avoided and a discrete or inline R2R process can be realized. Such machines are typically highly customized and of large footprint with machineand room-specific auxiliary equipment such as ventilation,
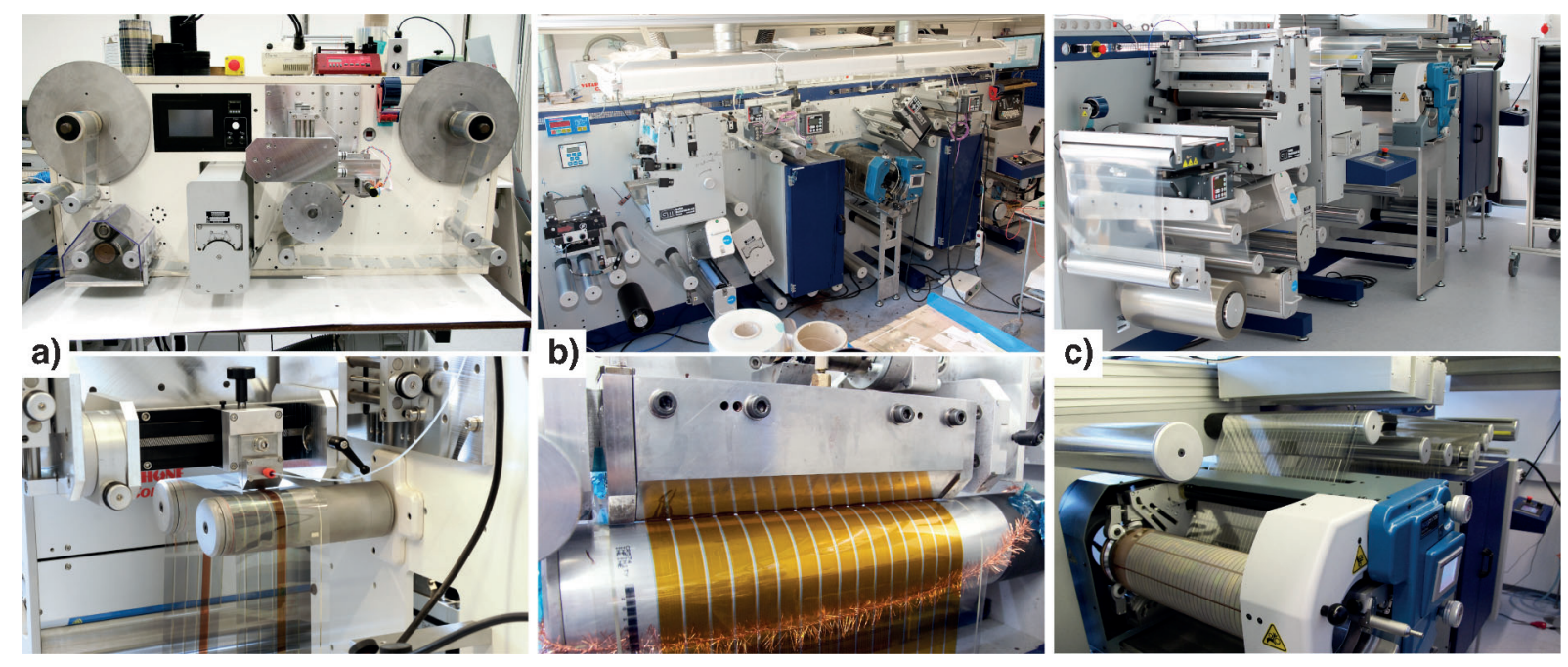

Figure 4. a) A machine for small-scale continuous R2R slot-die coating and other printing methods. b) R2R printing and coating machinery for web widths up to $305 \mathrm{~mm}$. The bottom photograph shows the slot-die coating of 16 active layer stripes. c) Upscaled R2R equipment with industrial character for web widths up to $510 \mathrm{~mm}$. The bottom photograph shows the rotary screen printing of a transparent conductive polymer on flexo-printed silver grid electrodes in a width of $510 \mathrm{~mm}$ and in full registration (in both web and cross-web directions). 


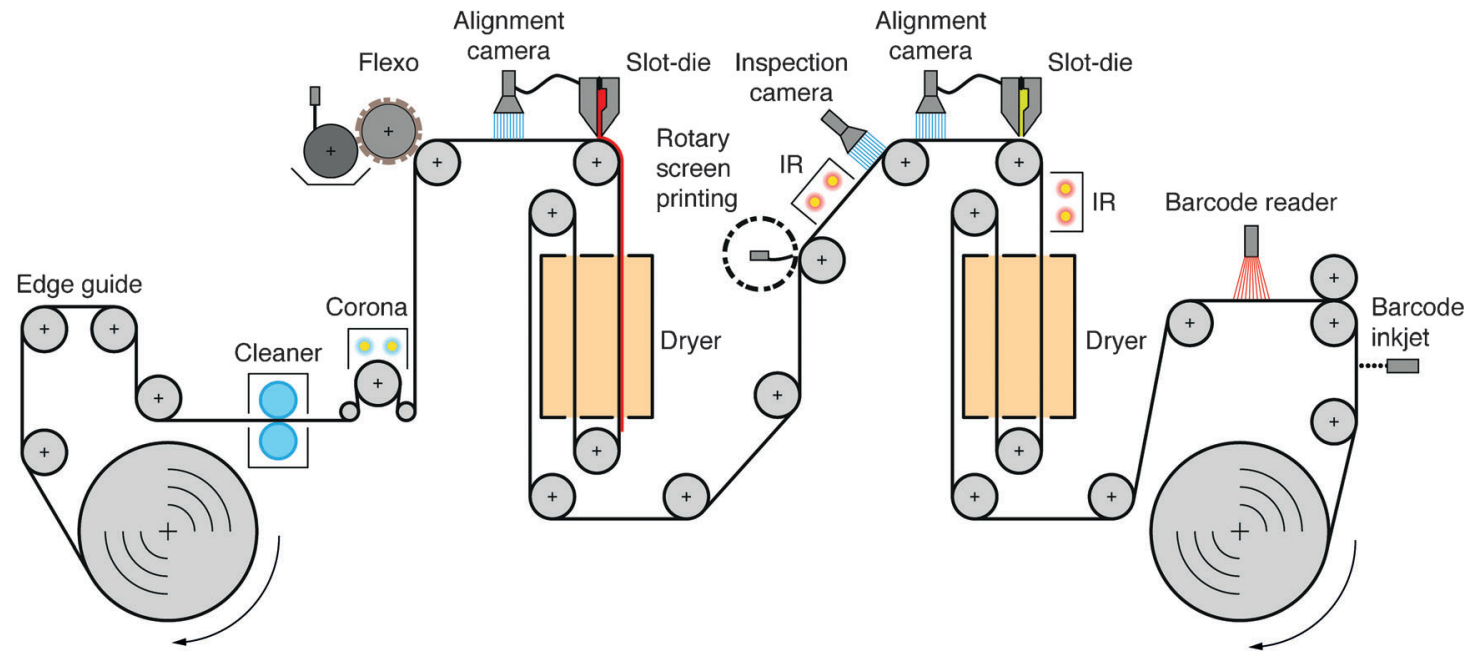

Figure 5. Schematics of a large-scale R2R machine with multiple printing and coating units, drying sections, and auxiliary systems.

exhaust, water, and power supply. Additional systems such as edge guides, web cleaner, surface treatments (e.g., corona, plasma), camera inspection, antistatic units, a register mark reader, register control, web tension control, an ID labeler, and an ID reader allow for full control over the fabrication workflow.

Before proceeding to large-scale tests on such machines with a high quantity of valuable ink the process conditions for OPV or other printed PV devices are evaluated on the small-scale setups with a minimum amount of ink. The optimum layer stacks, materials, and process conditions are then transferred, tested, and further optimized on the large machines without starting from scratch. An exemplary and illustrative route for the upscaling of inkjet-printed electrodes and electronics from concept tools to large R2R setups has been published elsewhere. ${ }^{[114]}$ Modification of the process parameters is often necessary as not all parameters can be exactly scaled up (i.e., due to variations in the drying behavior from small to big ovens). The coating and printing units for laboratory testing machines should be optimized for low dead volumes and low ink waste levels without affecting the process conditions to avoid a high relative loss of valuable ink for short print runs. The deposition units for large-scale machines with high output volumes have to be optimized for superior reliability and process stability because unnecessary ink waste and sudden processing breakdowns lead to a significant loss of valuable goods. Such large deposition systems will therefore be used for known ink systems and standard process conditions rather than daily test runs.

The typical level of active layer material normally used in labs for fabricating a batch of organic solar cells with spin coating is on the order of $1 \mathrm{~mL}$ of solution with $20 \mathrm{mg}$ of polymer and acceptor materials used. Scaling this material quantity to coating heads on large-scale R2R machines with $300 \mathrm{~mm}$ width or larger already requires $50 \mathrm{~mL}$ of ink to fill the head before the coating process can be started. High-precision gear pumps enable accurate flow rates over very long production runs. Lead-in and lead-out times for ink flow sta- bilization and cross-web directional registration translates into material waste and it is crucial to minimize this to bring large-scale R2R methods to smaller laboratories. The polymer quantity necessary is in the gram range that leads to a steep increase in the required investment for performing this type of experiment with high-performance materials.

The goal for lab-scale equipment for fully solution-processed photovoltaics should therefore be to enable the use of the large-scale coating techniques in a small-scale setting, while retaining a connection to the original parameter space for the large-scale systems. A decrease in size to approximately $10 \mathrm{~mm}$ slot-die coating width could help to bridge the gap from research laboratories to coating machinery manufactures. An example of scaled-down slot-die deposition units for testing purposes is a mini slot-die head with an ultra-low dead volume of less than $50 \mu \mathrm{L}$, along with the use of appropriate high-performance liquid chromatography (HPLC) tubing and connecters, enables a total syringe-tocoating dead volume of less than $100 \mu$ L. Fairly cheap and standard syringe pumps enable a continuous flow rate over the required coating time. Photographs of the mini slot-die head and one for $300 \mathrm{~mm}$ web width are shown in Figure $4 \mathrm{a}$ and $b$. The primary advantage of using reductions in width is that most processing parameters are left unaffected and a later upscaled to widths of $300 \mathrm{~mm}$ or larger for industrial production, which can be easily fulfilled. The mini slot-die head not only allows coating experiments for new polymers and layer stacks on the mini roll coater, ${ }^{[72,73,112]}$ but it can also be integrated into large R2R machines for continuous-ratio and thickness experiments or multilayer coating. ${ }^{[11,115]}$

\section{Testing and analysis equipment}

Though the production of printed solar cells in large-scalecompatible settings can be difficult, the process of completing a testing regime stringent enough to weed out bad modules or cells is an equal or larger challenge. The need for rigorous testing and understanding of the individual layer for- 
mation is a requirement raised by the typical build-up of modules, where cells are serially connected and should therefore be evenly matched for optimal performance to be achieved. A further complication comes with the need to avoid defects in the various layers while both coating/printing and for the process of encapsulation; this is a general trend prescribed by the need for reducing the exposure of the organic materials to water and oxygen, which are known to be prime causes of degradation of the cell performance.

Methods applied for layer characterization on the small scale to large-scale R2R setups are often based on desktop methods, but adapted to the continuous measurement characteristics required for a continuous fabrication system. Examples of such inspection systems range from optical linescanning cameras for finding defects of a visual character in the coatings, ${ }^{[16]}$ to electrical and photoelectrical systems with automated platforms performing electrical contacting, illumination, and performance measurement while running the foil continuously through a R2R $I V$-testing system. ${ }^{[30]}$ A recent addition to the photoelectrical characterization methods is the use of a laser-beam-induced current (LBIC) systems as illustrated in Figure $6 \mathrm{a}$ and Figure $7 \mathrm{a},{ }^{[117]}$ which can also run in a R2R fashion similar to the line-scan cameras without relying on direct electrical contacting (Figure 6b). ${ }^{[18]}$ The LBIC system however, gives access to an analysis of the solar cell performance on a microscale level over large areas, summarizing the effects of visual defects and electrical defects, and enables the precise measurement of the active area for the solar cell. Other optical testing systems for final devices include photoluminescence imaging, electroluminescence imaging, and lock-in thermography and these methods allow further studies of defects and quality control. ${ }^{[119-121]}$

$\mathrm{X}$-ray scattering methods are a further characterization tool to probe morphology and molecular organization of active layers. A possible way to measure the drying characteristics of such films has been studied by X-ray diffraction and simultaneous film thickness measurements by batch-wise doctor blading of the active-layer inks on glass substrates. ${ }^{[122,123]}$ To better simulate the processes from actual $\mathrm{R} 2 \mathrm{R}$ processing, a micro $\mathrm{R} 2 \mathrm{R}$ system (as illustrated in Figure $6 \mathrm{c}$ and shown in Figure $7 \mathrm{~b}$ and $\mathrm{c}$ ) was developed that allows continuous slot-die coating of inks on flexible substrates and in situ studies under a variety of processing condi-
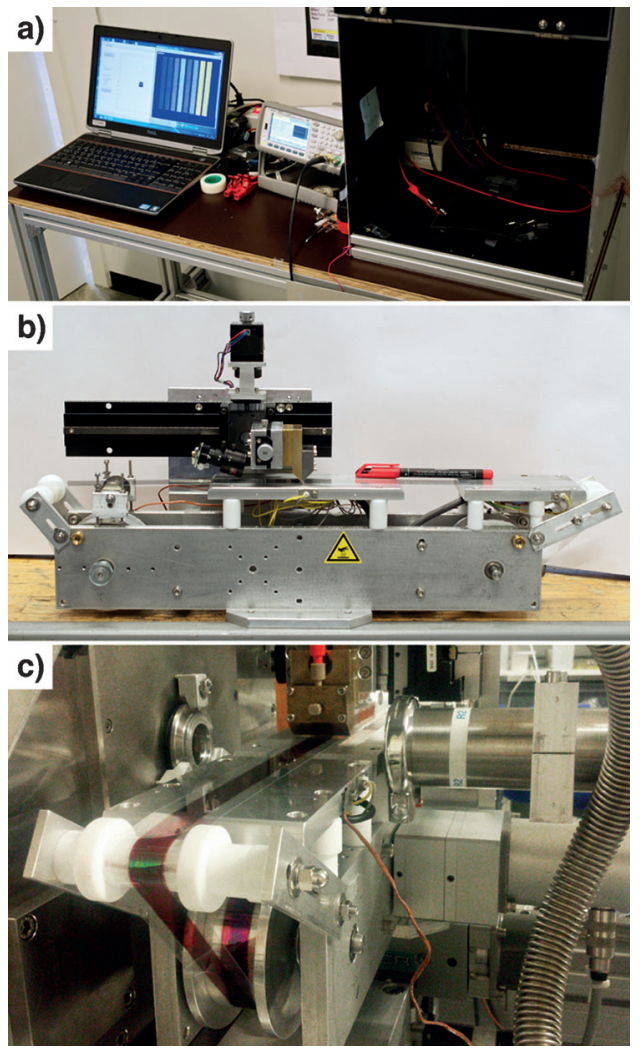

Figure 7. a) Desktop LBIC system with control units and dark measurement chamber (lid open for photograph). b) Micro R2R system for integration into $X$-ray testing setups. The scale bar is $10 \mathrm{~cm}$. c) The photograph shows a micro R2R setup under operation (slot-die coating of active layer) and integrated into a laboratory $\mathrm{X}$-ray source. The setup is fully remote controlled to allow integration into high-radiation environments.

tions including different drying temperatures and solvent additives. ${ }^{[124,125]}$

The setup is small enough to be transportable and can fit into laboratory X-ray sources and also synchrotron beam lines. ${ }^{[126]}$ It employs the same mini slot-die head and syringe pump system as described before. The system was used to study the interaction of the over-coating of several functional layers in organic tandem solar cells, and 3D X-ray phase contrast imaging (ptychography) gave further insight into a complete 12-layer solar cell stack. ${ }^{[127]}$ Another method that has been explored for in-line measurements of film thicknesses



a) Desktop LBIC

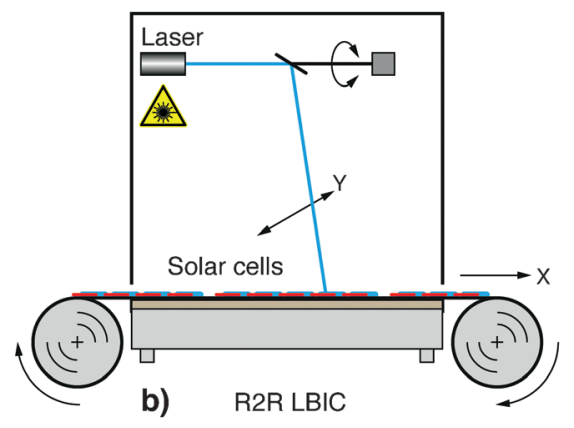

b) R2R LBIC

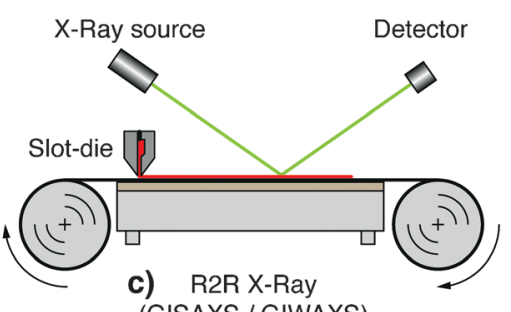

(GISAXS / GIWAXS)

Figure 6. Simplified illustrations of a) desktop-based LBIC, b) continuous R2R LBIC, and c) X-ray analysis using an integrated micro R2R system. 


\begin{tabular}{|c|c|c|c|c|c|c|}
\hline & Spin Coating & Roll setup & Micro/mini R2R & Inline experimental setup $\mathrm{R} 2 \mathrm{R}$ & Industrialized se & tup R2R \\
\hline footprint & very small & small & small & medium & medium-large & \\
\hline fume hood & yes & yes & yes & no (possible w. special housing) & no & \\
\hline glove box & yes & yes & & yes/no & no & no \\
\hline inert atmosphere & yes & yes & & yes/no & no & no \\
\hline clean room & yes & yes & & yes & yes & yes \\
\hline process & batch & batch & & continuous & continuous & continuous \\
\hline ink requirement & $>0.1 \mathrm{~mL}$ & $>0.5 \mathrm{ml}$ & $>0.5 \mathrm{~mL}$ & $>50 \mathrm{~mL}$ & $>100 \mathrm{~mL}$ & \\
\hline ink efficiency (per run) & $<1 \%$ & $>50 \%$ & $>80 \%$ & $>95 \%$ & $>99 \%$ & \\
\hline processed area $\left[\mathrm{m}^{2} \mathrm{~h}^{-1}\right]$ & $<0.1$ & $<1$ & $<10$ & $<500$ & $<2000$ & \\
\hline web speed $\left[\mathrm{m} \mathrm{min}^{-1}\right]^{[a]}$ & N.A. & 2 & $20^{[a]}$ & 30 & 60 & \\
\hline annual capacity ${ }^{[b]}$ & $1 \mathrm{~kW}$ & $8 \mathrm{~kW}$ & $80 \mathrm{~kW}$ & $4 \mathrm{MW}$ & $16 \mathrm{MW}$ & \\
\hline
\end{tabular}

and optical properties of OPV-specific layers is spectroscopic ellipsometry. ${ }^{[128]}$ The high-speed measurement system has been integrated into an experimental $\mathrm{R} 2 \mathrm{R}$ gravure printing machine to study printed transparent electrodes, active layer inks, and barrier layers under different processing conditions such as corona treatment or drying temperature.

\section{Future and Outlook}

Energy materials science as a field has made many discoveries and demonstrated potential for great progress during the past 20 years. The progression however hinges crucially on industrial and societal uptake that so far has received limited appreciation. One step in this direction is the opening of routes that energy materials technology can follow out of laboratories and into industry through upscaling. This approach allows developments in energy materials science and serves the purpose of making the often alleged technological marvels available for industries but also for testing in potential end user scenarios. Critical to this is that processes and machinery are available such that a relatively small investment in mainly time and materials allows one to take a laboratory energy technology through different scales of processing equipment to a larger scale. Future work should focus on using such platforms to penetrate into society and accelerate rational materials design based on the actual needs required by the large-scale processing.

\section{Conclusions}

Fully printed and solution-based coated energy technology, as exemplified here through solar cells, independent of their working principle, represents the researchers' dream since the time that solution-processible materials became available. We have reviewed applicable and solution-processible PV technologies from OPV over DSSC to fast-emerging perovskite solar cells and showed that only a limited number of these cells are fully solution processed, with some layers still evaporated. In most cases very slow growth or vacuum evaporation steps are involved and only some layers, not necessa- rily the most important active layer, can actually be printed or coated using large-scale compatible methods. Of course $\mathrm{R} 2 \mathrm{R}$ vacuum processing of single layers or entire OPV modules is feasible and in the commercialization phase (Solarmer, Heliatek), but definitely requires more specialized equipment and large investments. This Review also shows the discrepancy in efficiencies between lab-scale fabrication and large-scale methods on big machinery. This report gives an overview and workflow, from small-scale deposition systems to large-scale machinery, that enables efficient upscaling of printing and coating technologies for solution-based photovoltaics. We have shown through several examples the possibilities of increasing the use of large-scale-compatible methods in production of organic solar cells, without increasing the required material amount and infrastructure, as is generally required for conventional large experimental and industrially sized R2R setups. A concluding comparison of the fabrication strategies of printed and coated solar cells is summarized in Table 4.

\section{Acknowledgements}

This work was supported by Energinet.dk (project no. 10728 and 12144), the Danish Ministry of Science, Innovation and Higher Education under a Sapere Aude Top Scientist grant (no. DFF-1335-00037A) and an Elite Scientist grant (no. 11116028), and Tønder Energi og Miljøfond.

Keywords: organic photovoltaics • perovskites • polymers • roll-to-roll processing $\cdot$ solar cells

[1] C.-C. Chen, W.-H. Chang, K. Yoshimura, K. Ohya, J. You, J. Gao, Z. Hong, Y. Yang, Adv. Mater. 2014, 26, 5670-5677.

[2] M. A. Green, K. Emery, Y. Hishikawa, W. Warta, E. D. Dunlop, Prog. Photovolt. Res. Appl. 2014, 22, 701-710.

[3] M. Jørgensen, J. E. Carlé, R. R. Søndergaard, M. Lauritzen, N. A. Dagnæs-Hansen, S. L. Byskov, T. R. Andersen, T. T. Larsen-Olsen, A. P. L. Böttiger, B. Andreasen, L. Fu, L. Zuo, Y. Liu, E. Bundgaard, X. Zhan, H. Chen, F. C. Krebs, Solar Energy Mater. Solar Cells 2013, 119, 84-93. 
[4] F. Yan, J. Noble, J. Peltola, S. Wicks, S. Balasubramanian, Solar Energy Mater. Solar Cells 2013, 114, 214-218.

[5] F. C. Krebs, N. Espinosa, M. Hösel, R. R. Søndergaard, M. Jørgensen, Adv. Mater. 2014, 26, 29-39.

[6] S. Hong, M. Yi, H. Kang, J. Kong, W. Lee, J.-R. Kim, K. Lee, Solar Energy Mater. Solar Cells 2014, 126, 107-112.

[7] M. A. Green, A. Ho-Baillie, H. J. Snaith, Nat. Photonics 2014, 8, $506-514$.

[8] M. Grätzel, Nat. Mater. 2014, 13, 838-842.

[9] C. Deibel, V. Dyakonov, Rep. Prog. Phys. 2010, 73, 096401

[10] P. W. M. Blom, V. D. Mihailetchi, L. J. A. Koster, D. E. Markov, Adv. Mater. 2007, 19, 1551-1566.

[11] T. Ameri, N. Li, C. J. Brabec, Energy Environ. Sci. 2013, 6, 2390 2413.

[12] M. C. Scharber, N. S. Sariciftci, Prog. Polym. Sci. 2013, 38, 19291940.

[13] M. C. Scharber, D. Muhlbacher, M. Koppe, P. Denk, C. Waldauf, A Heeger, C. J. Brabec, Adv. Mater. 2006, 18, 789-794.

[14] M. Jørgensen, K. Norrman, S. A. Gevorgyan, T. Tromholt, B. Andreasen, F. C. Krebs, Adv. Mater. 2012, 24, 580-612.

[15] L. Dou, J. You, Z. Hong, Z. Xu, G. Li, R. A. Street, Y. Yang, Adv. Mater. 2013, 25, 6642-6671.

[16] S. E. Habas, H. A. S. Platt, M. F. A. M. V. Hest, D. S. Ginley, Chem. Rev. 2010, 110, 6571-6594.

[17] T. Todorov, D. Mitzi, Eur. J. Inorg. Chem. 2010, 2010, 17-28.

[18] M. G. Panthani, V. Akhavan, B. Goodfellow, J. P. Schmidtke, L. Dunn, A. Dodabalapur, P. F. Barbara, B. A. Korgel, J. Am. Chem. Soc. 2008, 130, 16770-16777.

[19] T. K. Todorov, O. Gunawan, T. Gokmen, D. B. Mitzi, Prog. Photovolt. Res. Appl. 2013, 21, 82-87.

[20] A. Hagfeldt, G. Boschloo, L. Sun, L. Kloo, H. Pettersson, Chem. Rev. 2010, 110, 6595-6663.

[21] P. Docampo, S. Guldin, T. Leijtens, N. K. Noel, U. Steiner, H. J. Snaith, Adv. Mater. 2014, 26, 4013-4030.

[22] A. Fakharuddin, R. Jose, T. M. Brown, F. Fabregat-Santiago, J. Bisquert, Energy Environ. Sci. 2014, 7, 3952-3981.

[23] S. Mathew, A. Yella, P. Gao, R. Humphry-Baker, B. F. E. Curchod, N. Ashari-Astani, I. Tavernelli, U. Rothlisberger, M. K. Nazeeruddin, M. Grätzel, Nat. Chem. 2014, 6, 242-247.

[24] P. Gao, M. Grätzel, M. K. Nazeeruddin, Energy Environ. Sci. 2014, 7, 2448-2463.

[25] F. Hao, C. C. Stoumpos, D. H. Cao, R. P. H. Chang, M. G. Kanatzidis, Nat. Photonics 2014, 8, 489-494.

[26] N. K. Noel, S. D. Stranks, A. Abate, C. Wehrenfennig, S. Guarnera, A.-A. Haghighirad, A. Sadhanala, G. E. Eperon, S. K. Pathak, M. B. Johnston, A. Petrozza, L. M. Herz, H. J. Snaith, Energy Environ. Sci. 2014, 7, 3061-3068.

[27] I. Burgués-Ceballos, M. Stella, P. Lacharmoise, E. Martínez-Ferrero J. Mater. Chem. A 2014, 2, 17711-17722.

[28] R. Søndergaard, M. Hösel, D. Angmo, T. T. Larsen-Olsen, F. C. Krebs, Mater. Today 2012, 15, 36-49.

[29] F. C. Krebs, Solar Energy Mater. Solar Cells 2009, 93, 394-412.

[30] F. C. Krebs, T. Tromholt, M. Jørgensen, Nanoscale 2010, 2, 873-886.

[31] C. J. Mulligan, M. Wilson, G. Bryant, B. Vaughan, X. Zhou, W. J. Belcher, P. C. Dastoor, Solar Energy Mater. Solar Cells 2014, 120 , 9-17.

[32] F. Machui, M. Hösel, N. Li, G. D. Spyropoulos, T. Ameri, R. R. Søndergaard, M. Jørgensen, A. Scheel, D. Gaiser, K. Kreul, D. Lenssen, M. Legros, N. Lemaître, M. Vilkman, M. Välimäki, S. Nordman, C. J. Brabec, F. C. Krebs, Energy Environ. Sci. 2014, 7, 2792-2802.

[33] N. Espinosa, M. Hösel, D. Angmo, F. C. Krebs, Energy Environ. Sci. 2012, 5, 5117-5132.

[34] J. Willmann, D. Stocker, E. Dörsam, Org. Electron. 2014, 15, 1631 1640.

[35] R. Po, A. Bernardi, A. Calabrese, C. Carbonera, G. Corso, A. Pellegrino, Energy Environ. Sci. 2014, 7, 925-943.

[36] M. Schulz-Ruhtenberg, T. Kolbusch, S. Abreu Fernandes, M. Wiesner, T. Melle, S. Bergfeld, M. Brosda, M. Schaefer, M. Ivanenko, A. Ostendorf, Laser Tech. J. 2014, 11, 21-25.

[37] T. Petsch, J. Haenel, M. Clair, B. Keiper, C. Scholz, Proc. SPIE 2011, 79210U.
[38] P. Kubis, N. Li, T. Stubhan, F. Machui, G. J. Matt, M. M. Voigt, C. J. Brabec, Prog. Photovolt. Res. Appl., in press, DOI: 10.1002/ pip. 2421.

[39] P. Apilo, J. Hiltunen, M. Välimäki, S. Heinilehto, R. Sliz, J. Hast, Prog. Photovolt. Res. Appl., in press, DOI: 10.1002/pip.2508.

[40] L. Wengeler, B. Schmidt-Hansberg, K. Peters, P. Scharfer, W. Schabel, Chem. Eng. Process. 2011, 50, 478-482.

[41] S.-L. Lim, E.-C. Chen, C.-Y. Chen, K.-H. Ong, Z.-K. Chen, H.-F. Meng, Solar Energy Mater. Solar Cells 2012, 107, 292-297.

[42] J.-H. Chang, Y.-H. Chen, H.-W. Lin, Y.-T. Lin, H.-F. Meng, E.-C. Chen, Org. Electron. 2012, 13, 705-709.

[43] B. Muhsin, R. Roesch, G. Gobsch, H. Hoppe, Solar Energy Mater. Solar Cells 2014, 130, 551-554.

[44] A. Schneider, N. Traut, M. Hamburger, Solar Energy Mater. Solar Cells 2014, 126, 149-154.

[45] M. M. Voigt, R. C. I. Mackenzie, S. P. King, C. P. Yau, P. Atienzar, J. Dane, P. E. Keivanidis, I. Zadrazil, D. D. C. Bradley, J. Nelson, Solar Energy Mater. Solar Cells 2012, 105, 77-85.

[46] M. M. Voigt, R. C. I. Mackenzie, C. P. Yau, P. Atienzar, J. Dane, P. E. Keivanidis, D. D. C. Bradley, J. Nelson, Solar Energy Mater Solar Cells 2011, 95, 731-734.

[47] J. M. Ding, A. de la Fuente Vornbrock, C. Ting, V. Subramanian, Solar Energy Mater. Solar Cells 2009, 93, 459-464.

[48] P. Kopola, T. Aernouts, R. Sliz, S. Guillerez, M. Ylikunnari, D. Cheyns, M. Välimäki, M. Tuomikoski, J. Hast, G. Jabbour, R. Myllylä, A. Maaninen, Solar Energy Mater. Solar Cells 2011, 95, 13441347.

[49] P. Kopola, S. Guillerez, H. Jin, M. Tuomikoski, A. Maaninen, J. Hast, Solar Energy Mater. Solar Cells 2010, 94, 1673-1680.

[50] S. Schiefer, B. Zimmermann, U. Würfel, Solar Energy Mater. Solar Cells 2013, 115, 29-35.

[51] B. Zimmermann, H. F. Schleiermacher, M. Niggemann, U. Würfel, Solar Energy Mater. Solar Cells 2011, 95, 1587-1589.

[52] S. Hong, J. Lee, H. Kang, K. Lee, Solar Energy Mater. Solar Cells 2013, 112, 27-35.

[53] F. Jakubka, M. Heyder, F. Machui, J. Kaschta, D. Eggerath, W. Lövenich, F. C. Krebs, C. J. Brabec, Solar Energy Mater. Solar Cells 2013, 109, 120-125.

[54] F. Machui, L. Lucera, G. D. Spyropoulos, J. Cordero, A. S. Ali, P. Kubis, T. Ameri, M. M. Voigt, C. J. Brabec, Solar Energy Mater. Solar Cells 2014, 128, 441-446.

[55] P. Kubis, L. Lucera, F. Machui, G. Spyropoulos, Org. Electron. 2014 15, 2256-2263.

[56] M. Senghor, M. Manceau, F. Ardiaca, R. de Bettignies, S. Berson, L. Dassas, S. Poughon, C. Dossou-Yovo, R. Noguera, Proc. SPIE 2012 84770M.

[57] T. Aernouts, T. Aleksandrov, C. Girotto, J. Genoe, J. Poortmans, Appl. Phys. Lett. 2008, 92, 033306.

[58] Y. Galagan, E. W. C. Coenen, S. Sabik, H. H. Gorter, M. Barink, S. C. Veenstra, J. M. Kroon, R. Andriessen, P. W. M. Blom, Solar Energy Mater. Solar Cells 2012, 104, 32-38.

[59] A. Lange, W. Schindler, M. Wegener, K. Fostiropoulos, S. Janietz, Solar Energy Mater. Solar Cells 2013, 109, 104-110.

[60] A. Lange, A. Hollaender, M. Wegener, Mater. Sci. Eng. B 2013, 178, 299-305.

[61] Y.-C. Huang, F.-H. Hsu, H.-C. Cha, C.-M. Chuang, C.-S. Tsao, C.-Y. Chen, Org. Electron. 2013, 14, 2809-2817.

[62] F. Hermerschmidt, P. Papagiorgis, A. Savva, C. Christodoulou, G. Itskos, S. A. Choulis, Solar Energy Mater. Solar Cells 2014, 130, $474-480$.

[63] F. C. Krebs, M. Jørgensen, K. Norrman, O. Hagemann, J. Alstrup, T. Nielsen, J. Fyenbo, K. Larsen, J. Kristensen, Solar Energy Mater. Solar Cells 2009, 93, 422-441.

[64] B. Zhang, H. Chae, S. Cho, Jpn. J. Appl. Phys 2009, 48, 020208.

[65] L. La Notte, D. Mineo, G. Polino, G. Susanna, F. Brunetti, T. M. Brown, A. Di Carlo, A. Reale, Energy Technol. 2013, 1, 757-762.

[66] J.-W. Kang, Y.-J. Kang, S. Jung, M. Song, D.-G. Kim, C. S. Kim, S. H. Kim, Solar Energy Mater. Solar Cells 2012, 103, 76-79.

[67] J.-W. Kang, Y.-J. Kang, S. Jung, D. S. You, M. Song, C. S. Kim, D.-G. Kim, J.-K. Kim, S. H. Kim, Org. Electron. 2012, 13, 2940-2944. 
[68] S.-I. Na, B.-K. Yu, S.-S. Kim, D. Vak, T.-S. Kim, J.-S. Yeo, D.-Y Kim, Solar Energy Mater. Solar Cells 2010, 94, 1333-1337.

[69] C. N. Hoth, R. Steim, P. Schilinsky, S. A. Choulis, S. Tedde, O. Hayden, C. J. Brabec, Org. Electron. 2009, 10, 587-593.

[70] H. F. Dam, F. C. Krebs, Solar Energy Mater. Solar Cells 2012, 97, 191-196.

[71] J. E. Carlé, M. Helgesen, M. V. Madsen, E. Bundgaard, F. C. Krebs, J. Mater. Chem. C 2014, 2, 1290-1297.

[72] J. E. Carlé, M. Helgesen, N. K. Zawacka, M. V. Madsen, E. Bundgaard, F. C. Krebs, J. Polym. Sci. B 2014, 52, 893-899.

[73] T. R. Andersen, H. F. Dam, B. Andreasen, M. Hösel, M. V. Madsen, S. A. Gevorgyan, R. R. Søndergaard, M. Jørgensen, F. C. Krebs, Solar Energy Mater. Solar Cells 2014, 120, 735-743.

[74] D. Angmo, H. F. Dam, T. R. Andersen, N. K. Zawacka, M. V. Madsen, J. Stubager, F. Livi, R. Gupta, M. Helgesen, J. E. Carlé, T. T. Larsen-Olsen, G. U. Kulkarni, E. Bundgaard, F. C. Krebs, Energy Technol. 2014, 2, 651-659.

[75] C. Koidis, S. Logothetidis, S. Kassavetis, C. Kapnopoulos, P. G. Karagiannidis, D. Georgiou, A. Laskarakis, Solar Energy Mater. Solar Cells 2013, 112, 36-46.

[76] C. Koidis, S. Logothetidis, A. Ioakeimidis, A. Laskarakis, C. Kapnopoulos, Org. Electron. 2013, 14, 1744-1748.

[77] H.-C. Cha, Y.-C. Huang, F.-H. Hsu, C.-M. Chuang, D.-H. Lu, C.-W Chou, C.-Y. Chen, C.-S. Tsao, Solar Energy Mater. Solar Cells 2014, 130, 191-198.

[78] L. Blankenburg, K. Schultheis, H. Schache, S. Sensfuss, M. Schrödner, Solar Energy Mater. Solar Cells 2009, 93, 476-483.

[79] M. Schrödner, S. Sensfuss, H. Schache, K. Schultheis, T. Welzel, K. Heinemann, R. Milker, J. Marten, L. Blankenburg, Solar Energy Mater. Solar Cells 2012, 107, 283-291.

[80] F. C. Krebs, S. A. Gevorgyan, J. Alstrup, J. Mater. Chem. 2009, 19, $5442-5451$.

[81] F. C. Krebs, Org. Electron. 2009, 10, 761-768.

[82] A. C. Hübler, B. Trnovec, T. Zillger, M. Ali, N. Wetzold, M. Mingebach, A. Wagenpfahl, C. Deibel, V. Dyakonov, Adv. Energy Mater. 2011, 1, 1018-1022.

[83] M. Tuomikoski, P. Kopola, H. Jin, M. Ylikunnari, J. Hiitola-Keinanen, M. Välimäki, M. Aikio, J. Hast, Microelectronics and Packaging Conference, 2009, EMPC 2009 European (Rimini), 2009, 1-4.

[84] D. Kaduwal, H.-F. Schleiermacher, J. Schulz-Gericke, T. Kroyer, B. Zimmermann, U. Würfel, Solar Energy Mater. Solar Cells 2014, 124, 92-97.

[85] Y. Galagan, I. G. de Vries, A. P. Langen, R. Andriessen, W. J. H. Verhees, S. C. Veenstra, J. M. Kroon, Chem. Eng. Process. 2011, 50, 454-461.

[86] F. C. Krebs, J. Fyenbo, M. Jørgensen, J. Mater. Chem. 2010, 20 , 8994-9001.

[87] M. Hösel, R. R. Søndergaard, M. Jørgensen, F. C. Krebs, Energy Technol. 2013, 1, 102-107.

[88] T. R. Andersen, H. F. Dam, M. Hösel, M. Helgesen, J. E. Carlé, T. T. Larsen-Olsen, S. A. Gevorgyan, J. W. Andreasen, J. Adams, N. Li, F. Machui, G. D. Spyropoulos, T. Ameri, N. Lemaitre, M. Legros, A. Scheel, D. Gaiser, K. Kreul, S. Berny, O. R. Lozman, S. Nordman, M. Välimäki, M. Vilkman, R. R. Søndergaard, M. Jørgensen, C. J. Brabec, F. C. Krebs, Energy Environ. Sci. 2014, 7, 2925-2933.

[89] F. C. Krebs, M. Hösel, M. Corazza, B. Roth, M. V. Madsen, S. A Gevorgyan, R. R. Søndergaard, D. Karg, M. Jørgensen, Energy Technol. 2013, 1, 378-381.

[90] G. A. dos Reis Benatto, B. Roth, M. V. Madsen, M. Hösel, R. R Søndergaard, M. Jørgensen, F. C. Krebs, Adv. Energy Mater. 2014, 4, 1400732

[91] J.-S. Yu, I. Kim, J.-S. Kim, J. Jo, T. T. Larsen-Olsen, R. R. Søndergaard, M. Hösel, D. Angmo, M. Jørgensen, F. C. Krebs, Nanoscale 2012, 4, 6032-6040.

[92] W. Wang, S.-Y. Han, S.-J. Sung, D.-H. Kim, C.-H. Chang, Phys. Chem. Chem. Phys. 2012, 14, 11154-11159.

[93] M. Singh, J. Jiu, T. Sugahara, K. Suganuma, ACS Appl. Mater. Interfaces 2014, 6, 16297-16303.

[94] V. K. Kapur, A. Bansal, P. Le, O. I. Asensio, Thin Solid Films 2003, $431-432,53-57$
[95] V. Kapur, A. Bansal, P. Le, O. Asensio, Twenty-Ninth IEEE Photovoltaic Specialists Conference 2002, 688-691.

[96] W. Wang, Y.-W. Su, C.-H. Chang, Solar Energy Mater. Solar Cells 2011, 95, 2616-2620.

[97] U. Berner, M. Widenmeyer, Prog. Photovolt. Res. Appl., in press, DOI: 10.1002/pip.2546.

[98] K. Zhang, C. Qin, X. Yang, A. Islam, S. Zhang, H. Chen, L. Han, Adv. Energy Mater. 2014, 4, 1301966.

[99] G. Y. Margulis, M. G. Christoforo, D. Lam, Z. M. Beiley, A. R. Bowring, C. D. Bailie, A. Salleo, M. D. McGehee, Adv. Energy Mater. 2013, 3, 1657-1663.

[100] H. Santa-Nokki, J. Kallioinen, T. Kololuoma, V. Tuboltsev, J. Korppi-Tommola, J. Photochem. Photobiol. A 2006, 182, 187-191.

[101] M. Hu, L. Liu, A. Mei, Y. Yang, T. Liu, H. Han, J. Mater. Chem. A 2014, 2, 17115-17121.

[102] A. T. Barrows, A. J. Pearson, C. K. Kwak, A. D. F. Dunbar, A. R. Buckley, D. G. Lidzey, Energy Environ. Sci. 2014, 7, 2944-2950.

[103] A. Mei, X. Li, L. Liu, Z. Ku, T. Liu, Y. Rong, M. Xu, M. Hu, J. Chen, Y. Yang, M. Grätzel, H. Han, Science 2014, 345, 295-298.

[104] F. Matteocci, S. Razza, F. Di Giacomo, S. Casaluci, G. Mincuzzi, T. M. Brown, A. D'Epifanio, S. Licoccia, A. Di Carlo, Phys. Chem. Chem. Phys. 2014, 16, 3918-3923.

[105] J. Burschka, N. Pellet, S.-J. Moon, R. Humphry-Baker, P. Gao, M. K. Nazeeruddin, M. Grätzel, Nature 2013, 499, 316-319.

[106] F. Zhang, X. Yang, H. Wang, M. Cheng, J.-H. Zhao, L. Sun, ACS Appl. Mater. Interfaces 2014, 6, 16140-16146.

[107] C.-S. Huang, H.-T. Lin, G.-S. Huang, J.-P. Hu, S.-T. Lu, C. T. Liu, S Garner, J.-C. Lin, K.-T. Kuo, G. Merz, J. Tosch, C. Chang, SID Int. Symp. Dig. Tech. Pap. 2013, 44, 807-809.

[108] Corning, Corning Willow Glass, http://www.corning.com/displaytechnologies/en/products/flexible.aspx

[109] S. Sheehan, P. K. Surolia, O. Byrne, S. Garner, P. Cimo, X. Li, D. P. Dowling, K. R. Thampi, Solar Energy Mater. Solar Cells 2015, 132, 237-244.

[110] J. E. Carlé, T. R. Andersen, M. Helgesen, E. Bundgaard, M. Jørgensen, F. C. Krebs, Solar Energy Mater. Solar Cells 2013, 108, 126128

[111] J. Alstrup, M. Jørgensen, A. Medford, F. C. Krebs, ACS Appl. Mater. Interfaces 2010, 2, 2819-2827.

[112] M. Helgesen, J. E. Carlé, F. C. Krebs, Adv. Energy Mater. 2013, 3, $1664-1669$

[113] J. Jensen, H. F. Dam, J. R. Reynolds, A. L. Dyer, F. C. Krebs, J. Polym. Sci. B 2012, 50, 536-545.

[114] R. Abbel, P. Teunissen, E. Rubingh, T. van Lammeren, R. Cauchois, M. Everaars, J. Valeton, S. van de Geijn, P. Groen, Trans. Mater Res. 2014, 1, 015002.

[115] T. T. Larsen-Olsen, B. Andreasen, T. R. Andersen, A. P. L. Böttiger, E. Bundgaard, K. Norrman, J. W. Andreasen, M. Jørgensen, F. C. Krebs, Solar Energy Mater. Solar Cells 2012, 97, 22-27.

[116] N. Espinosa, F. O. Lenzmann, S. Ryley, D. Angmo, M. Hösel, R. R. Søndergaard, D. Huss, S. Dafinger, S. Gritsch, J. M. Kroon, M. Jørgensen, F. C. Krebs, J. Mater. Chem. A 2013, 1, 7037-7049.

[117] F. C. Krebs, R. Søndergaard, M. Jørgensen, Solar Energy Mater. Solar Cells 2011, 95, 1348-1353.

[118] F. C. Krebs, M. Jørgensen, Adv. Opt. Mater. 2014, 2, 465-477.

[119] R. Rösch, F. C. Krebs, D. M. Tanenbaum, H. Hoppe, Solar Energy Mater. Solar Cells 2012, 97, 176-180.

[120] R. Rösch, D. M. Tanenbaum, M. Jørgensen, M. Seeland, M. Bärenklau, M. Hermenau, E. Voroshazi, M. T. Lloyd, Y. Galagan, B. Zimmermann, U. Würfel, M. Hösel, H. F. Dam, S. A. Gevorgyan, S. Kudret, W. Maes, L. Lutsen, D. Vanderzande, R. Andriessen, G. Teran-Escobar, M. Lira-Cantu, A. Rivaton, G. Y. Uzunoğlu, D. Germack, B. Andreasen, M. V. Madsen, K. Norrman, H. Hoppe, F. C. Krebs, Energy Environ. Sci. 2012, 5, 6521-6540.

[121] M. Seeland, R. Rösch, H. Hoppe, J. Appl. Phys. 2011, 109, 064513.

[122] M. Sanyal, B. Schmidt-Hansberg, M. F. G. Klein, A. Colsmann, C. Munuera, A. Vorobiev, U. Lemmer, W. Schabel, H. Dosch, E. Barrena, Adv. Energy Mater. 2011, 1, 363-367.

[123] B. Schmidt-Hansberg, M. F. G. Klein, M. Sanyal, F. Buss, G. Q. G. de Medeiros, C. Munuera, A. Vorobiev, A. Colsmann, P. Scharfer, U. 
Lemmer, E. Barrena, W. Schabel, Macromolecules 2012, 45, 7948 7955.

[124] A. P. L. Böttiger, M. Jørgensen, A. Menzel, F. C. Krebs, J. W. Andreasen, J. Mater. Chem. 2012, 22, 22501-22509.

[125] N. K. Zawacka, T. R. Andersen, J. W. Andreasen, L. H. Rossander, H. F. Dam, M. Jørgensen, F. C. Krebs, J. Mater. Chem. A 2014, 2, $18644-18654$.

[126] L. H. Rossander, N. K. Zawacka, H. F. Dam, F. C. Krebs, J. W. Andreasen, AIP Advances 2014, 4, 087105.

[127] H. F. Dam, T. R. Andersen, E. B. L. Pedersen, K. T. S. Thydén, M. Helgesen, J. E. Carlé, P. S. Jørgensen, J. Reinhardt, R. R. Sønder- gaard, M. Jørgensen, E. Bundgaard, F. C. Krebs, J. W. Andreasen, Adv. Energy Mater., in press, DOI: 10.1002/aenm.201400736.

[128] S. Logothetidis, D. Georgiou, A. Laskarakis, C. Koidis, N. Kalfagiannis, Solar Energy Mater. Solar Cells 2013, 112, 144-156.

Received: October 8, 2014

Revised: December 21, 2014

Published online on $\mathbf{\square} \mathbf{u}, 0000$ 


\section{REVIEWS}

Tipping the scale: Scaling of printed energy technologies requires the scaling of materials, machinery, and testing. We describe how the bridge between the small laboratory demonstration and large industrial manufacturing can be achieved through a rationally chosen set of machines with increasing scale. Efficient process development using a particular materials technology can efficiently be transferred from the small to the large machines with little loss.
M. Hösel, H. F. Dam, F. C. Krebs*

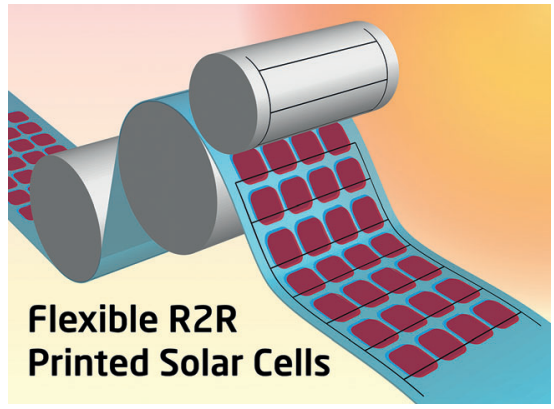

Development of Lab-to-Fab Production Equipment Across Several Length Scales for Printed Energy Technologies, Including Solar Cells 